\title{
ERDŐ EGÉSZSÉGI ÁLLAPOT VIZSGÁLATOK A KASZÓ-LIFE PROJEKT KERETÉBEN
}

\author{
Koltay András ${ }^{1}$, Fürjes-Mikó Ágnes ${ }^{1}$, Tenorio-Baigorria Imola ${ }^{1}$, Eötvös Csaba Béla ${ }^{1}$ \\ és Horváth László ${ }^{2}$ \\ ${ }^{1}$ NAIK ERTI Erdővédelmi Osztály, Mátrafüred \\ ${ }^{2}$ KASZÓ Zrt., Kaszó
}

\begin{abstract}
Kivonat
A 2014-2018 között megvalósult „KASZÓ-LIFE” program keretében élőhely rehabilitáció történt a KASZÓ Zrt. területén, enyves éger (Alnus glutinosa (L.) Gaertn.) és kocsányos tölgy (Quercus robur L.) állományokban. A területen vízvisszatartó létesítmények segítségével próbálják csökkenteni, illetve lassítani a talajvíz süllyedését, javítani az erdők talajának vízháztartását, és ezen keresztül az erdők egészségi állapotát. Az erdők egészségi állapotának megfigyelésére mintaterületeket jelöltünk ki, ahol évente két alkalommal rögzítettünk adatokat. Az adatokat összevetettük a talajvíz, csapadék és meteorológiai mérések eredményeivel. A rendszeres egészségi állapot felvételezésekkel felmértük a bekövetkezett változásokat, és meghatároztuk a területen rendszeresen előforduló kárformákat és ezek kiváltó okait. Az eddigi vizsgálatok adatai azt mutatják, hogy mind a tölgyek, mind az égerek esetében 2017-től már kisebb mértékủ javulás jelentkezett a kontroll területekhez képest. Ugyanakkor a vizsgált időszak relatív rövidsége miatt még nem lehet egyértelmü következtetéseket levonni a program sikerességéről, de a megfigyelések folytatásával erre is lehetőség nyílik a jövőben.
\end{abstract}

Kulcsszavak: KASZÓ-LIFE, erdő egészségi állapot, talajvízszint, enyves éger, kocsányos tölgy

\section{HEALTH CONDITION INVESTIGATION OF FORESTS IN KASZÓ-LIFE PROJECT}

\begin{abstract}
The „KASZÓ-LIFE” programme, which was developed between 2014 and 2018, aimed the restoration and improvement of the growing conditions of the Common alder (Alnus glutinosa) and the Pedunculate oak (Quercus robur) tree estimate. With the help of water retention facilities in the area, the reduction of the subsidence of groundwater was attempted, as well as the improvement of the water balance of the forest's soil, and thus the health of the forests. Sampling areas have been designated in order to monitor the health conditions of the forests where the tree examination is carried out twice a year. Comparing the health data along with the results of groundwater, precipitation and meteorological measurements, we may come to a conclusion in the future concerning the forthcoming changes exhibited in the forests. Examinations so far have shown that both in the case of oaks and alders, from 2017 there was a slight improvement comparing to the control areas. However, due to the relative shortness of the period, this does not yet clearly indicate the success of the programme, which must be supported by many years of test results.
\end{abstract}

Keywords: KASZÓ-LIFE, forest health condition, groundwater level, Alnus glutinosa, Quercus robur 


\section{BEVEZETÉS}

A termőhely és ezen belül a klimatikus viszonyok, az időjárás egyes elemeinek változásai nagymértékben befolyásolják az erdők fejlődését, az egyes fafajok elterjedési lehetőségeit, de e mellett nagy hatással vannak az erdők egészségi állapotának alakulására hazánkban és Európában egyaránt (Barcza et al 2011, Führer 2018, Michel et al 2019). Ez a hatás lehet közvetlen, azonnali hatás pl. viharkárok, vagy hosszabb távra ható tényezők, mint pl. az aszály. Az időjárás elemeinek változása rendszerint gyorsan és egyértelműen érzékelhető a fák, erdők egészségi állapotán, míg a klimatikus változások hatása rendszerint lassú folyamat, nehezebben azonosítható. A klímaváltozás ténye ma már nem megkérdőjelezhető és az is egyértelmünek tủnik, hogy a jövőben ezek a változások folyamatosan jelen lesznek, amire lehetőségeinkhez mérten fel kell készülnünk (Bartholy et al 2007, Lakatos \& Bihari 2011). Klimatikus szempontból leginkább a csapadék és hőmérséklet adatokkal jellemezhetö egy terület, e két paraméter van a legnagyobb hatással az erdökre, ezen belül az egészségi állapotra is (Csóka et al 2009). A jövőben egyre gyakoribbá váló aszályos időszakok, a várhatóan kevesebb csapadék és annak kedvezőtlen eloszlása nagy hatással lesz az egyes fafajok elterjedésére, vitalitására, növekedési viszonyaira és a mortalitás kockázatának emelkedésére (Gálos \& Führer 2018). Mindezek felvetik a termőhely változásának kérdését, ezen belül a vízellátottság erdőkre gyakorolt hatását. Amennyiben a szárazodás beigazolódik, úgy várhatóan a transpirációhoz szükséges talajból felvehető víz mennyisége is csökken, esetenként nem lesz elegendő a fák számára (Somogyi 2018). Ez folyamatos hő- és vízstresszhelyzetet teremt a fáknak, ami lehetővé teszi a különféle biotikus kárositók hatásainak felerősödését. E negatív hatások csökkentésére a változó klimatikus viszonyokhoz jobban adaptálódott szaporítóanyagot és szükség esetén akár új fafajokat kellene felkarolni (Borovics 2018), vagy a termőhelyi viszonyok negatív irányú változásait kellene csökkenteni. Ez utóbbira lehet megoldás az erdőterületek vízellátásának javitása, a zavartalan fejlődéshez szükséges csapadékvíz pótlása, az egyenetlen eloszlású csapadék visszatartása.

A „KASZÓ-LIFE” program élőhely rehabilitációt, azon belül az enyves éger (Alnus glutinosa) és kocsányos tölgy (Quercus robur) állományok termőhelyi viszonyainak helyreállitását, javitását tüzte ki célul. A közel 2100 hektáros projektterületen az erdők számára az alapvető problémát az elmúlt évtizedekben tapasztalható talajvizszint depressziója okozza, ami részben emberi beavatkozások (vízfolyások kanyarulatainak levágása, vízelvezető árkok épitése), részben pedig a manapság egyre jellemzőbb csökkenő mennyiségü és egyenetlen eloszlású csapadék következménye (Nagy \& Nagy 2012). Ennek eredményeként például a terület kiemelt természeti értékét képviselő Baláta tó vízszintje évről évre jelentős ingadozást mutat. A tagadhatatlanul bekövetkezett klímaváltozás a meglévő erdők, lápok élővilágára kedvezőtlenül hat, azok egészségi állapotának romlásához vezet, hosszú távon megmaradásukat veszélyezteti (Majer et al 2002). Azáltal, hogy a talajvízszint fokozatosan süllyed, elindul az érintett területen fellelhető élőhelyek szárazodása, melynek következménye, hogy az enyves éger és kocsányos tölgy alkotta ligeterdők - mivel köztudottan nagy a vízigényük - visszaszorulnak, helyükbe más, természetvédelmi szempontból kevésbé értékes élőhelyek lépnek. A szárazodás hatására megjelenhetnek és elterjedhetnek korábban a területen nem jellemző, invazív növényfajok, idegenhonos kárositók, kórokozók, így megnőhet az erdőgazdálkodás szempontjából nemkívánatos rovar és gombafajok kártétele. Mindezek mellett a klímaváltozás eredményeként szélsőségessé váló időjárási tényezők, viharok, kései fagyok és egyéb káros hatások ugyancsak komoly veszélyt jelentenek az erdők számára (Tóth 2003).

A „KASZÓ LIFE” program keretin belül végrehajtott beavatkozások célja közvetlenül vagy közvetve e nemkivánatos hatások megállitását, visszafordítását célozza, az időjárás okozta szélsőségek hatásainak mérséklésével, a lehullott csapadék vízfolyásokon történő levonulásának lassításával és a víz helyben tartásával.

Az alábbiakban bemutatjuk a projekt keretében vizsgált kocsányos tölgy és enyves éger mintaparcellákban, 2014-2019 között bekövetkezett változásokat, elsősorban a fák egészségi állapotára és a leggyakrabban előforduló kárformákra fókuszálva. 


\section{ANYAG ÉS MÓDSZER}

A projekt első éveiben a területen található, korábban a Taranyi-Rinya vizének felduzzasztásával létesített Kűvölgyi-tórendszer rehabilitációja történt. Mederkotrással, mélyítéssel, új völgyzáró gátak kialakításával állandósították a tavak vízszintjét, továbbá két új tó kialakítása is megvalósult 2016 végére. Ezekkel a beavatkozásokkal az eredeti, összesen 7 hektár nagyságú két tavat, négy tóból álló, közel 16 hektáros tórendszerré bővítették, amely $135000 \mathrm{~m}^{3}$ vizet tud tárolni, ezzel folyamatos talajvíz-vízutánpótlást biztosítva a környező erdőknek. Belső-Somogy erdőterületeit sekély medrű időszakos (nyári időszakban kiszáradó) vízfolyások, népi elnevezéssel rinyák hálózzák be. Ezek kanyargós medrét korábban több helyen szabályozták, vagyis kiegyenesítették és kimélyítették (Nagy \& Nagy 2012). Ennek következtében a víz gyorsabban folyik le, így a környező erdők csak rövidebb ideig tudják a számukra nélkülözhetetlen vizet hasznosítani. Ezért a leérkező csapadék lokális visszatartása, tározása érdekében, mederbordákat helyeztek el, hogy a lehulló csapadék minél hosszabban maradjon a területen. A vízfolyások mintegy 15 km hosszú szakaszára a terepadottságoktól függően, átlagosan 100 méterenként fából készült mederbordák lettek beépitve, összesen 123 darab, amelyek elkészülte ugyancsak 2016 végére tehető. A folyásirányra merőleges mederbordák lassítják a lefolyást, megemelik a vízszintet. Ennek köszönhetően a medrekben lefolyó víz nagyobb hányada szivároghat a talajba, ezzel emelve a talajvíz szintjét.

A fentiekben bemutatott vízvisszatartás erdőkre gyakorolt hatásainak vizsgálatára monitoring rendszert alakítottak ki. Ennek egyik eleme a Kaszó belterületén, 2014 októberében üzembe helyezett agrometeorológiai állomás (http://met.boreas.hu/erti/), amelynek feladata az alapvető meteorológiai paraméterek mérése, különös tekintettel a vízforgalom bemeneti oldalára, illetve az azt leginkább befolyásoló tényezőkre, mint a csapadék és hőmérséklet. A számos meteorológiai adat mérése mellett a talajvízszint változásainak nyomon követésére 2014 májusában 14 talajvíz kutat létesítettek a projekt területén kijelölt mintaparcellákban, valamint 4 kutat a kontroll területeken. A vízszint változásait heti rendszerességgel jegyezték fel.

A beavatkozások erdőkre gyakorolt hatásainak vizsgálatára 18 mintaterületet jelöltünk ki 2014 tavaszán. A projekt területén 10 éger és 4 kocsányos tölgy, míg kontrollként a vízvisszatartással nem érintett területen 2 éger és 2 kocsányos tölgy parcellát alakítottunk ki (1. ábra). A mintaterületeken 100-100 állandósított, egyedileg számozott mintafán vizsgáltuk az egészségi állapot alakulását. 2014-2018 között folyamatosan monitoroztuk az erdőket évi két alkalommal, május végén és szeptember elején, meghatározva a fák részletes egészségi viszonyait, a lombkoronától a törzsön át a gyökfőig, feljegyezve valamennyi látható elváltozást, károsodást. Mivel a „KASZÓ-LIFE” projekt 2018 decemberében befejeződött, így 2019-től utókövetés történik, ezért az egészségi állapot felvételeket csak ősszel végezzük. A megfigyelési adatokat feldolgoztuk, értékeltük, valamint összevetettük a talajvíz és meteorológiai adatokkal.

Az erdőkben bekövetkező állapotváltozások, hosszú távú megfigyelések megvalósítása csak objektív alapokon nyugvó, világos, egyértelmű vizsgálati metodikával biztosítható. Ezt a célt szolgálja a NAIK Erdészeti Tudományos Intézetében is alkalmazott, nemzetközi erdőállapot felmérési metodika, melyet az Európai Unió tagállamainak szakértői dolgoztak ki a '80-as évek közepén (Eichhorn et al 2016). Magyarországon 1989 óta használják ezt az egységesített és a tagállamok által elfogadott metodikát, amelyet az elmúlt évek során többször átalakítottak, továbbfejlesztettek.

A felvételezések során, valamennyi mintaterületen az összes számozott mintafa egészségi állapotát rögzítjük, így a koronában a lombozat, az ágak, a törzs és a gyökfő minőségét, a lehetséges összes paramétert figyelembe véve határozzuk meg. A lombvesztést egy, az adott területre jellemző teljesen egészséges fához, mint etalonhoz mérve becsüljük meg 5\%-os pontossággal. A többi paramétert 10\%-os ugrásokkal rögzítjük. Amennyiben mód van rá, azonosítjuk az adott egyedeken előforduló kártevők, kórokozók pontos körét, előfordulását és felmérjük az általuk okozott károk mértékét. A biotikus eredetű károsodások mellett meghatározzuk az abiotikus eredetű károkat is. Ennek meghatározásában és azonosításában nagy szerepe van a meteoro- 
lógiai állomás adatainak. A felvételezések során látott kárképek és a meteorológiai adatok összevetésével pontosabban megállapítható például egy viharkár okozta levélvesztés, vagy ágelhalás, esetenként a kései fagyokból eredő lombelszíneződés, hervadás. Az így begyűjtött idősoros adatok alapján elemezzük és határozzuk meg az egyes állományokban bekövetkezett változásokat.

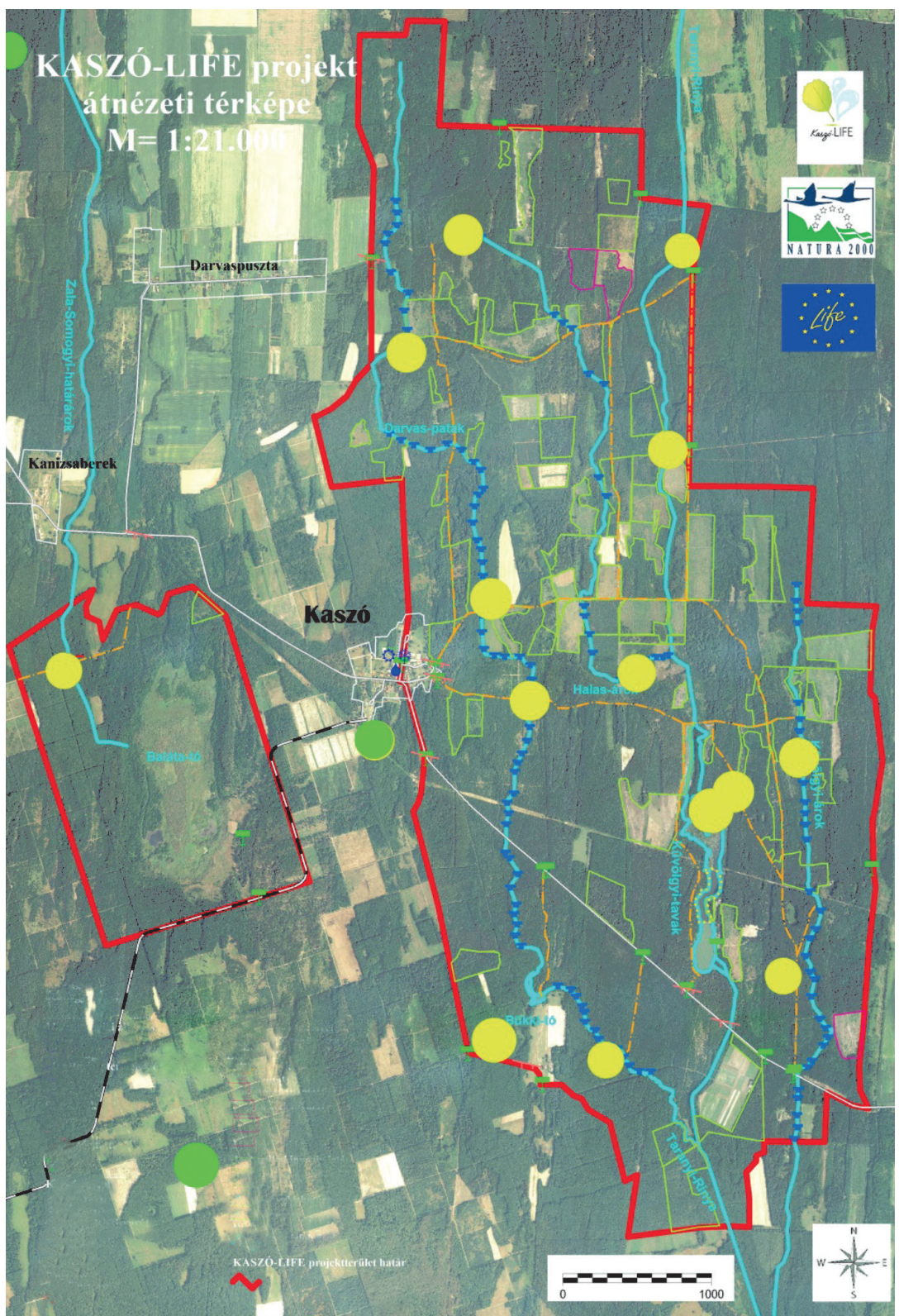

1. ábra: A projekt áttekintő térképe a mintapontokkal

Jelmagyarázat: $\bigcirc$ Mintaterület $\bigcirc$ Kontroll Projekt terület határa Figure 1: The map of the project with experimental plots

Legend: $\bigcirc$ Experimental plot $\bigcirc$ Control Border of project area 
Az egészségi állapot felvételeket évente két alkalommal végeztük. Az elsőt - az időjárási viszonyokat figyelembe véve - május végén, június első felében, amikor a tavasszal, kora nyáron előforduló károsítók, kórokozók jelenléte nyilvánvaló, valamint a tavaszi, téli abiotikus hatások még jól azonosíthatók. A második felvételezést augusztus végén, szeptember elején, amikor a vegetációs időszak utolsó harmadában már jól láthatóak az éves változások kumulált tünetei, de nem jelennek még meg az őszi lombvesztésből adódó természetes elváltozások. E felvételek összesített adatai alapján pontosan meghatározható és leírható az adott állomány általános egészségi állapota és a változások mértéke, iránya. Az adatok kiértékelésekor, a grafikonokon az őszi felvételi adatokat mutatjuk be, mivel ezek az őszi adatok tükrözik leginkább az állományokban bekövetkezett egészségi állapot változások kumulált, tényleges hatásait.

A felvételi metodika a terepi felvételek mellett magában foglalta a folyamatos vizuális adatrögzítést is. Valamennyi mintaparcellában, évről évre ugyanazon „etalon” fákról fénykép készült, amely fotó rögzíti az adott parcellában álló, tipikus egészséges, valamint egy beteg fa jellegzetességeit. E fotók dokumentálják az egészségi állapot besorolások adott állományra vonatkozó viszonyítási értékeit. Mindezeken túl az állományok egészéről is fotó dokumentáció készült, kiegészítve a jellegzetes kárképekkel, az egészségi állapotot leginkább befolyásoló tényezők digitális fotókkal való rögzítésével.

\section{EREDMÉNYEK ÉS MEGVITATÁSUK}

\section{Levélvesztés}

Az egészségi állapotra vonatkozó adatokat összesítve megállapítható, hogy a 2014-2019 közötti időszakban változatosan alakult a fák egészségi állapota mind a projekt területen mind a kontroll állományokban egyaránt. Elsőként a levélvesztést kell kiemelni, mivel ez a legfontosabb és egyben legszembetünőbb paraméter a fák egészségi állapotát tekintve. A lombfogyasztók, kórokozók illetve az abiotikus hatások elsősorban a lombfelületet érintik, illetve az egészséges lombfelület arányát csökkentik. Ezek mellett a fiziológiai hatások, a talaj minősége, tápanyagtartalma, nedvességi viszonyainak anomáliái szintén a lombfelület csökkenésében, vagy rendellenes elszíneződésében, alakváltozásaiban nyilvánulnak meg.

Az idősoros adatok elemzései azt mutatják, hogy az évről évre jelentkező átlagos lombvesztés mértéke az égerek esetében 5-10\%-os sávban mozog, míg a tölgyeknél ez az arány 15-20\% körül alakult a vizsgált időszakban. A két fafaj lombvesztésében adódó különbség természetesnek mondható, mivel az égereken élő kártevők, kórokozók száma jóval kisebb, mint a tölgyeken élőké. Az adatok szerint az égerek esetében 2016 őszéig az átlagos lombvesztés értéke minden esetben nagyobb volt a projekt területén, míg 2017-től ez az arány megfordult, és a következő években már a kontroll területeken mutatkozott magasabb átlagos levélvesztés. Ugyanakkor meg kell jegyezni, hogy az eltérés kezdetben nagyon minimális volt, nem érte el a 0,5\%-ot, de 2017-től a különbség évről évre emelkedett, és 2019-ben már 9,3\%-os eltérést regisztráltunk. Az égerekhez hasonlóan az átlagos lombvesztésben bekövetkezett változás a tölgyek esetében is megfigyelhető volt. 2017 elött a kontroll területek fáin észleltük az alacsonyabb értékeket, míg 2017-töl a projekt területén mutatkozott a kisebb levélvesztés. Ugyanakkor meg kell jegyezni, hogy a tölgyeknél az eltérés minimális a kontroll és projekt területek között, mindössze 1-2\% (2-3. ábra). 


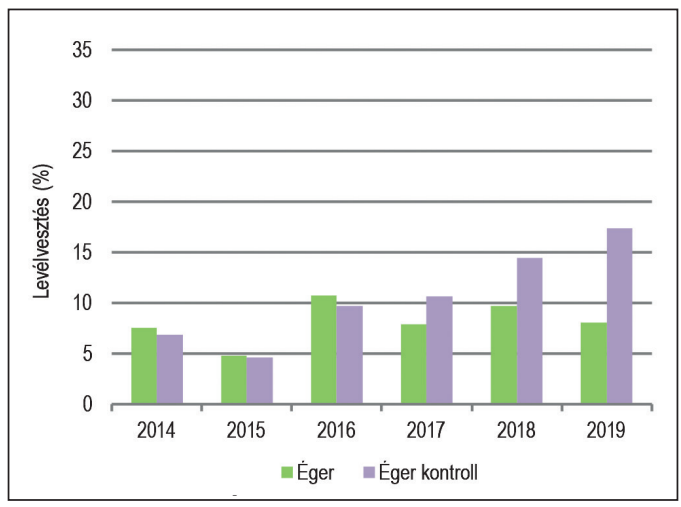

2. ábra: Átlagos levélvesztés égereken 2014-2019 őszi adatok

Figure 2: Average defoliation on Common alders 2014-2019, autumn data

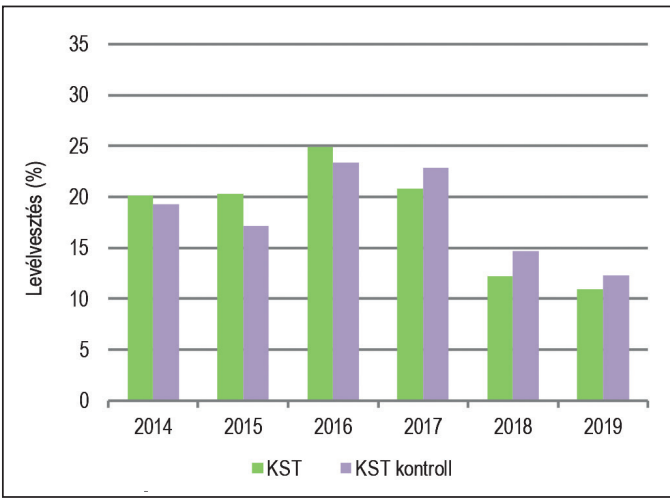

3. ábra: Átlagos levélvesztés kocsányos tölgyeken 2014-2019 őszi adatok

Figure 3: Average defoliation on Pedunculate oaks 2014-2019, autumn data

\section{Ágelhalás}

A fák egészségi állapotának másik kiemelten fontos paramétere az ágelhalás mértéke. Az ágelhalás mértékének megállapitása során a vékonyabb ágak és a vázágak elhalását is figyelembe vettük, összevontan kezeltük. A vizsgált években több esetben söpört végig nagy erejü szél a kaszói erdőtömb területén, jelentős károkat okozva a koronákban. (2015 májusában két alkalommal, 13-án 13,9 m/s, 27-én 12,6 m/s, 2016-ban június 17-én 12,3 m/s, július 16-án 14,7 m/s, 2017-ben április 20-án 16,2 m/s, május 21-én 13,8 $\mathrm{m} / \mathrm{s}$, június 29 -én $15,8 \mathrm{~m} / \mathrm{s}$ erejü széllökéseket rögzített az állomás.) Az erős széllökések hatására egymáshoz csapódó koronákban gyakran sérült a lombozat valamint a vékonyabb ágak, hajtások, de ez nem járt a vázágak elhalásával. A vázág elhalások jellemzően a leromlásos tünetek jellegzetes kíséröi, rendszerint xilofág rovarok károsítása, vagy parazita gombafajok támadása miatt alakulnak ki. A vázágak elhalása permanensen jelen lévő tünet, míg a vékonyabb ágak képesek regenerálódni, ezért az ágelhalás értékei is évről évre változhatnak.

Az égerek esetében az átlagos ágelhalás már a vizsgálatok kezdete óta alacsonyabb a projekt területén, mint a kontroll területeken. Ezzel szemben a tölgyeknél fordított a helyzet, 2017 tavaszáig a kontroll területek állományaiban volt alacsonyabb ez az érték. Ugyanakkor 2017 őszére fordult a helyzet és a kontroll állományokban regisztráltunk nagyobb mértékủ ágelhalást. A különbség 2018-ban is megmaradt, de 2019-ben ismét a kontroll területen jelentkezett kisebb mértékủ ágelhalás. Ezek az eltérések, ingadozások minimálisak, 1-2\%-ot tesznek ki. Az ágelhalásban jelentkező eltérések egyelöre nem tekinthetők trendszerünek, a hosszabbtávú vizsgálati eredmények adhatnak majd pontosabb választ az esetlegesen kialakuló trendekröl (4-5. ábra).

A tavaszi lombvesztési és ágelhalási adatokat ugyancsak vizsgáltuk, összevetve az őszi adatsorokkal, de jellemzően a tavaszi felvételek adatait inkább tájékoztató jellegünek tekintettük az aktuális károsítások azonositásához. A tavaszi felvételek többnyire az állományokban előforduló tavaszi, kora nyári aszpektusú kárformák felvételezését, regisztrálását szolgálják. Az őszre kialakuló korona állapot az, ami jellemzően tükrözi a vegetációs időszakban bekövetkező károk összességét. 


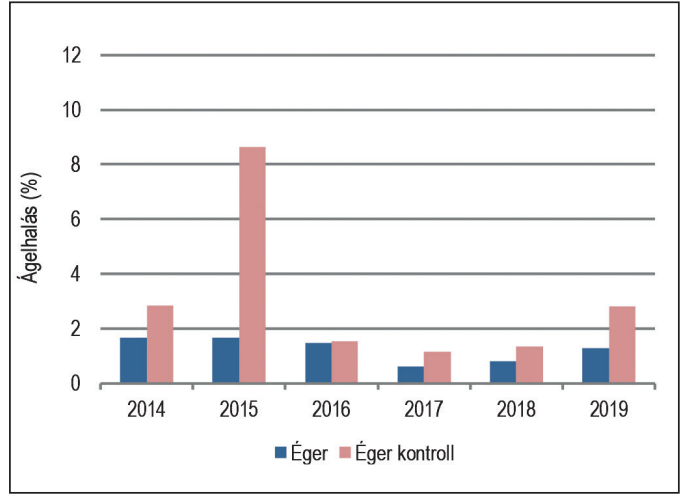

4. ábra: Átlagos ágelhalás égereken 2014-2019 őszi adatok

Figure 4: Average branch dieback on Common alders, 2014-2019, autumn data

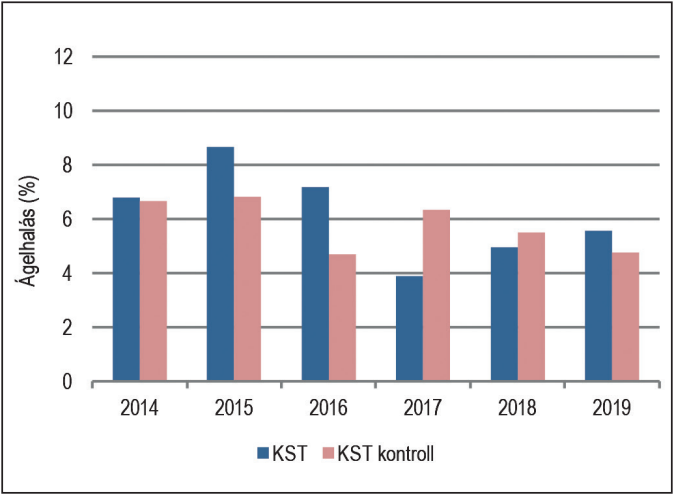

5. ábra: Átlagos ágelhalás kocsányos tölgyeken 2014-2019 őszi adatok

Figure 5: Average branch dieback on Pedunculate oaks, 2014-2019, autumn data

\section{Kárformák}

Az állományokban előforduló károsodásokat kiváltó okokat vizsgálva megállapítható, hogy az éger és a tölgy esetében természetszerűen más-más tényezők hatása dominál. A kárformákban és az azokat kiváltó tényezőkben a tavaszi és őszi felvételek adatai is eltéréseket mutatnak (kései fagykár, levélgombák, lombrágás), mivel az egyes kiváltó tényezők szezonalitása más és más. Többek között ez is indokolta az évi két alkalommal végzett felvételezéseket.

Az égeresekben tavasszal, évről évre kiemelkedő kárforma a lombrágás, valamint esetenként a szél (2014), vagy a fagy (2016). Ősszel ugyancsak a lombrágás a domináns kárforma, de e-mellett a leromlás, alászorultság, kéreggomba és levélgomba kárképei is megjelennek (6-7. ábra). A fák átlagos egészségi állapotát jól jellemzi az úgynevezett leromlásos tünet együttes. Ennek közvetlen kiváltó oka nem azonosítható, ugyanakkor lombvesztésben és ágelhalásban nyilvánul meg, rendszerint többtényezős, komplex hatások következtében. Ennek a kárformának a gyakorisága tükrözi leginkább egy állomány átlagos egészségi állapotát. Ezt figyelembe véve megállapítható, hogy az égerek esetében ez a kárforma 2015 őszétől folyamatosan csökken. Meg kell ugyanakkor jegyezni, hogy a kontroll területeken is hasonló tendencia figyelhető meg. A különféle kárformák hasonlóak a kontroll és a projekt területén álló égerek esetében, de a projekt területén lévő égerekben három kárforma is jelentkezett, amit a kontroll területek esetében nem észleltünk. Ennek oka a projekt területen lévő parcellák nagyobb számából, másrészt a mikroklimatikus viszonyok eltéréséből adódott. 2016 tavaszán, április 26 -án $-2,9^{\circ} \mathrm{C}$ minimum hőmérsékletet mért az állomás, amelynek eredményeként a mélyebb fekvésű projekt parcellákban jelentkezett kisebb mértékű lombkárosodás a lombfakadás idején, ugyanakkor a kontroll területek kevéssé fagyzugos parcelláin nem észleltünk fagykárokat. $A$ projekt területén e mellett levél- és kéreggomba okozta károkat is észleltünk. A levélen a tüneteket az Asteroma alneum (Pers. ex Fr.) Sutton (1980) levélgomba okozta, de csak két egymást követő évben (2014-2015), majd ezt követően nem jelentkezett ez a kárforma. Ezzel szemben a fitoftórás kéregfoltosodás Phytophthora alni Brasier \& S. A. Kirk (2004) tünete folyamatosan jelen van az állományokban. A fitoftórás fertőzés elsődleges tünetei a fa törzsén jelennek meg sötétbarna, fekete kátrányfoltok formájában a kéreg felületén.

A lombrágás okozta levélvesztés a kárformákon belül a legjelentősebb hányadot képviseli. Évről évre a kárformák 60-80\%-át ez teszi ki. Túlnyomó része, az égerek leggyakoribb lombfogyasztója, a kék égerlevelész (Agelastica alni Linnaeus, 1758) rágása miatt következett be. A tünetek az egész vegetációs időszak folyamán jelen vannak, mivel az álcák és a kifejlett bogár is fogyasztja a leveleket. 


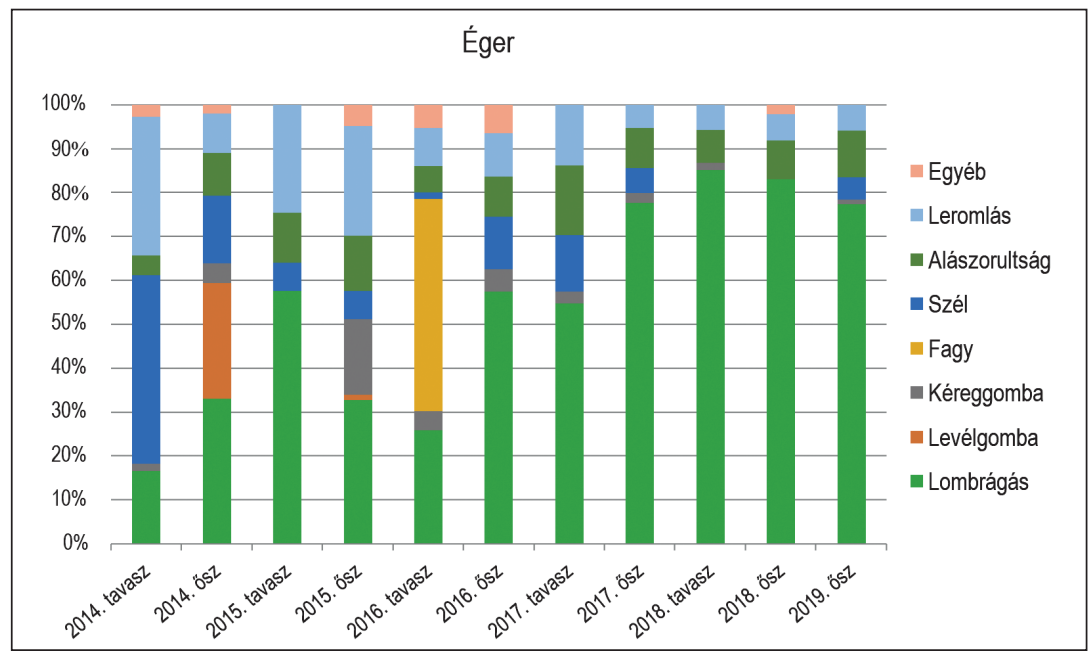

6. ábra: A kárformák elöfordulási gyakorisága égeren 2014-2019 között

Figure 6: Frequency of damage forms on Common alder, 2014-2019

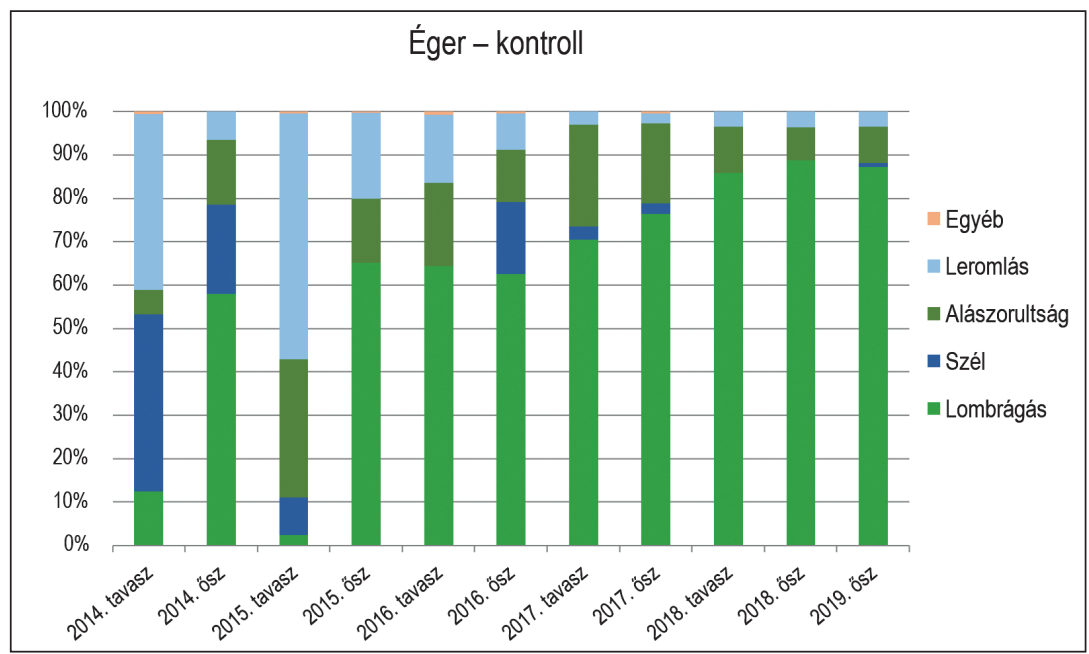

7. ábra: Kárformák elöfordulási gyakorisága az éger kontroll területeken 2014-2019 között Figure 7: Frequency of damage forms in control areas of Common alder - control, 2014-2019

Tölgyek esetében a leromlásos tünetek fordulnak elö legnagyobb arányban, 40-60\%-os gyakorisággal. A projekt területén 2015-2016-ban figyeltük meg ennek a kárformának jelentősebb előfordulását, majd 2017ben - az egyéb kárformák nagyobb mértékủ megjelenése miatt - az összes kárformán belül aránya kissé csökkent, majd 2018 tavaszán ismét a legjelentősebb kárforma volt (8-9. ábra). A leromlásos tüneteket jelenlegi ismereteink szerint elsődlegesen a szárazodás illetve az aszályosság idézi elő (Csóka et al 2009), így jelentősége kiemelt a projekt szempontjából. Ugyanakkor a kaszói vizsgálati eredmények nem támasztják alá egyértelmüen ezt a megállapitást, bár megitélésünk szerint ebben szerepe lehet a vizsgálati időszak relatív rövidségének.

A kárformák között évről évre ugyancsak jelentős szerepet játszik a szél okozta lombvesztés és vékonyág károsodás, ami az egyre gyakoribb és hevesebb viharoknak köszönhető (Részletes adatokat lásd fentebb). 
2016-ban a tölgyeken is észleltünk tavaszi fagykáros tüneteket, de ezek nyomait az őszi felvételezések során már nem lehetett regisztrálni. A tölgyeken még évröl évre kiemelt szerepet játszik a tölgylisztharmat gomba (Erysiphe alphitoides (Griffon \& Maubl.) U. Braun \& S. Takam. 2000) fertőzése.

A vizsgált években a lombrágás csak kisebb arányban jelentkezett az állományokban. A projekt területén és a kontroll parcellákban hasonló jellegű és mértékű károsodások jelentkeztek, bár éppen a leromlásos tünetek terén mutatkozott kisebb eltérés. Míg a kontroll parcellákban ennek aránya az őszi felvételezések szerint évről évre szinte állandó, addig a projekt területén lévő állományokban 2015-2016-ban magas arányban fordult elő ez a kárforma, míg 2017-ben előfordulási gyakorisága csökkent, de 2018-ra újra meghatározóvá vált (7-8. ábra). A kontroll területeken évről évre jelen van a kétsávos díszbogár (Coraebus florentinus Herbst. 1801) fertőzés, amely elsősorban a koronák felső részén jelentkezik.

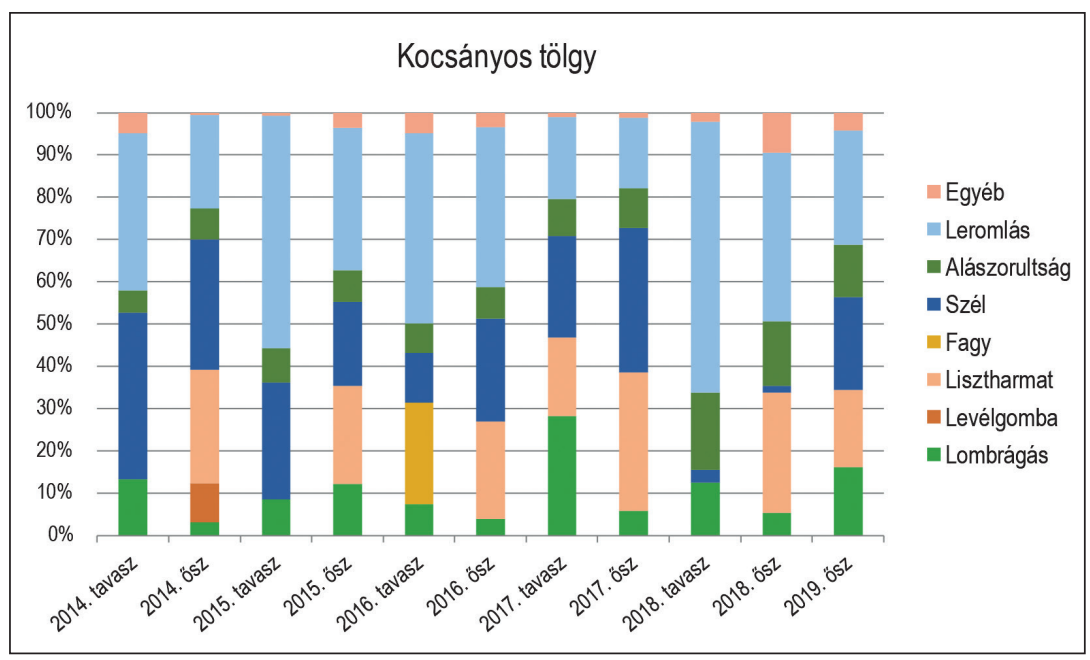

8. ábra: Kárformák elöfordulási gyakorisága kocsányos tölgyön 2014-2019 között

Figure 8: Frequency of damage forms on Pedunculate oak, 2014-2019

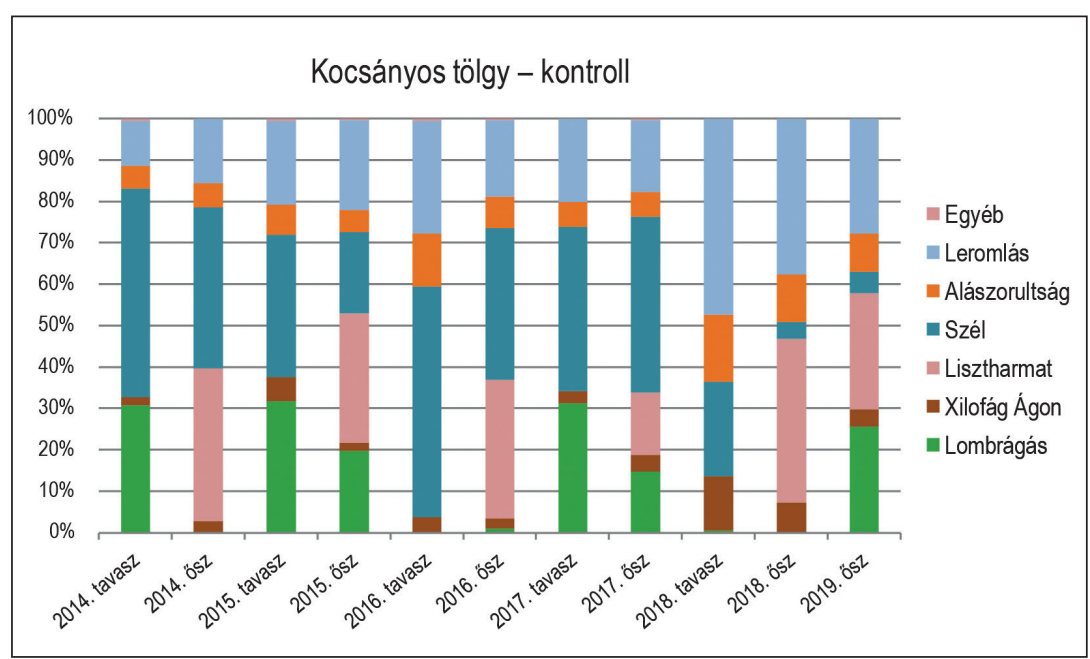

9. ábra: Kárformák elöfordulási gyakorisága kocsányos tölgy - kontroll 2014-2019 között

Figure 9: Frequency of damage forms on Pedunculate oak - control, 2014-2019 
A lombkárok között kell megemlíteni a tölgy-csipkéspoloska (Corythucha arcuata Say, 1832) levélfonákon történő szívogatása következtében fellépő klorofill-hiányos elszíneződést. Az inváziós rovart Somogy megyében 2017-ben találták meg (Paulin et al 2020), míg felvételeink során 2018-ban azonosítottuk először a rovar szórványos jelenlétét a mintaterületeken, illetve a kaszói erdőtömbben. 2019-ben már sokfelé észleltük a károkat, bár ezek többsége moderált volt. A 2020-as felvételeink során már széles körben jelen volt a károsító, tünetei gyakran kifejezetten erősnek tűntek, a koronák kifakulása, elszíneződése alapján. Mindössze három év elegendő volt a poloska tömeges elterjedéséhez a térségben. (A2020. évi felvételek adatai feldolgozás alatt vannak, a poloskára vonatkozó megfigyelések előzetes adatnak tekintendők)

\section{Csapadék és talajvíz}

Az egészségi állapot vizsgálatok mellett a projekt teljes időtartama alatt, majd azt követően is folyamatos a csapadék és talajvíz adatok gyüjtése. A csapadék és talajvíz szintjének elemzését 2014-2017 közötti időszakra vonatkozóan Eötvös \& Horváth (2018) végezte el. 2018-ig a talajvízszint süllyedése figyelhető meg mind a projekt területen, mind a kontroll mintavételi pontokon. Ugyanakkor a területen végzett beavatkozások hatására a talajvízszint süllyedés mérséklődött. A csapadék mennyiségében és eloszlásában nem figyelhető meg változás a sokéves átlaghoz képest, azonban az egyes esőzések intenzitása a klímaváltozás következtében egyre fokozódik, így a talajba szivárgás lehetősége csökken. (Eötvös \& Horváth 2018). A 2018-2019. évi adatokkal kiegészítve a korábbi adatsorokat, megállapítható, hogy a heti csapadékösszegek és az átlagos talajvízszintek a kontroll és a vizsgálati területeken a vízvisszatartó mütárgyak elkészülte után, a projekt terület talajvízszintje a kontroll területekhez képest egy magasabb szinten stabilizálódott. Nagyobb mennyiségü csapadékok után, jelentősebb mértékben és hosszabb időre emelkedik a talajvízszint a projekt területen, mint a kontroll területeken, ami azt mutatja, hogy a vízvisszatartás sikeres. Ugyanakkor mindkét területen csökkenő trendet lehet megfigyelni a talajvízszint esetében, azonban a projekt területén ez a csökkenés jóval kisebb mértékü (10. ábra).

A projekt keretében végzett évgyürüvizsgálatok és a talajvízszint észlelési adatainak összevetése hasonló összefüggést tárt fel. Az évgyűrű növekedési mérések szerint a kedvező folyamatok már észlelhetőek a vizsgált éger és tölgy állományokban. Bár a vízvisszatartást szolgáló beavatkozásokkal érintett projekt területen 2017-ben az éger állományok esetében is észleltek évgyürü méretbeli csökkenést, de jelentősen kisebb mértéküt, mint a kontroll területek állományaiban, holott az azt megelőző években fordított volt a helyzet (Garamszegi et al 2018).

\section{ÖSSZEFOGLALÁS}

A fentiekben bemutatott vizsgálati eredmények alapján megállapítható, hogy a vízvisszatartás kedvező hatásai megjelentek a kaszói erdőtömbben, de ezek tendenciózus változása egyelőre nem igazolható egyértelmüen. Az egészségi állapotra vonatkozó megállapítások egy hosszabb távú folyamat kezdeti eredményeinek tekinthetők. A víz és az erdő egészségi állapotának viszonya egy rendkívül összetett, soktényezős rendszer, amelynek folyamatait, a befolyásoló tényezőket és a változások irányát csak hosszabbtávú megfigyelések révén lehet megismerni, megérteni. Amennyiben kellő információval rendelkezünk a rendszer elemeire vonatkozóan, úgy képesek lehetünk a klímaváltozásból adódó anomáliákat, negatív folyamatokat korrigálni, vagy legalább-is kedvezőtlen hatásait csökkenteni. Ehhez azonban további vizsgálat és megfigyelés szükséges, amelyhez megteremtettük az első lépéseket a projekt megvalósításával. A vizsgálatok folytatása, a projekt hosszútávú utókövetése, lehetőséget teremt az összefüggések pontosabb feltárására. 


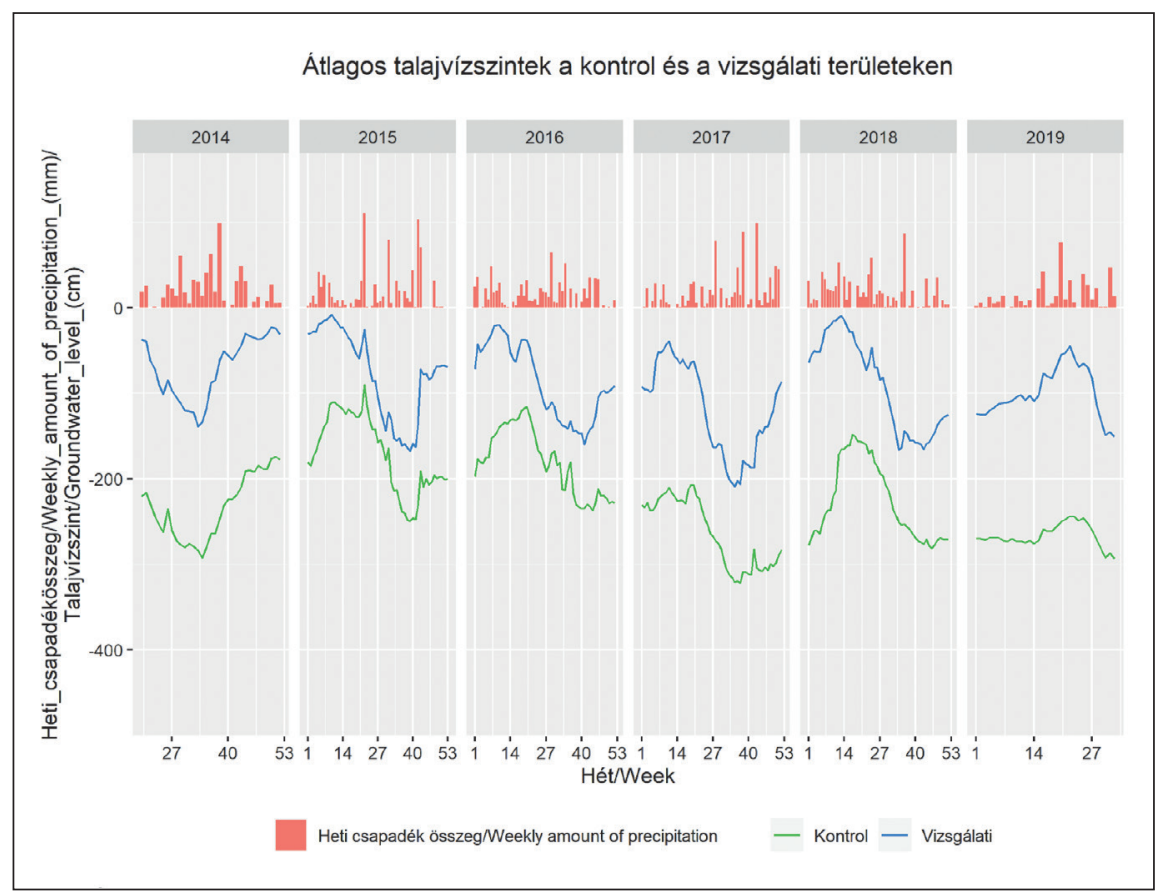

10. ábra: A csapadék és talajvízszint változásai a projekt és a kontroll területeken 2014-2019 között

Figure 10: Changes in precipitation and groundwater levels in the project and control areas, 2014-2019

\section{KÖSZÖNETNYILVÁNITTÁS}

A kutatás a „KASZÓ-LIFE” Projekt, 2014-2018. (LIFE12 NAT/HU/000593) támogatásával valósult meg. A program befejezését követően, 2019-től a KASZÓ Zrt. és a NAIK ERTI finanszírozásával folytatódnak a kutatások.

\section{FELHASZNÁLT IRODALOM}

Barcza Z., Bartholy J., Mészáros R., Pongrácz R., \& Radics K. 2011: Globális és európai tendenciák. In: Bartholy J., Bozó L. \& Haszpra J. (eds): KLÍMAVÁLTOZÁS - 2011 Klímaszcenáriók a Kárpát-medencetérségére. MTA és az ELTE Meteorológiai Tanszéke, Budapest, 99-144.

Bartholy J., Pongrácz R. \& Gelybó Gy. 2007: Regional climate change expected in Hungary for 2071-2100. Applied Ecology and Environmental Research 5(1): 1-17. DOI: 10.15666/aeer/0501_001017

Borovics A. 2018: A jövő már elkezdődött. A klímaváltozáshoz alkalmazkodó erdőgazdálkodás kihívásai - VIII. Erdészeti Lapok CLIII. évf.1: 2-5.

Csóka Gy., Koltay A., Hirka A. \& Janik G. 2009: Az aszályosság hatása kocsánytalan tölgyeseink és bükköseink egészségi állapotára. Klíma-21 füzetek 57: 64-73

Eichhorn J., Roskams P., Potočić N., Timmermann V., Ferretti M., Mues V., Szepesi A., Durrant D., Seletković I., Schröck H[W., Nevalainen S., Bussotti F., Garcia P. \& Wulff S. 2016: Part IV: Visual Assessment of Crown Condition and Damaging Agents. In: UNECE ICP Forests Programme Coordinating Centre (ed): Manual on methods and criteria for harmonized sampling, assessment, monitoring and analysis of the effects of air pollution on forests. Thünen Institute of Forest Ecosystems, Eberswalde, Germany, 49. + Annex [http://www.icp-forests.org/manual.htm]. 
Eötvös Cs. B. \& Horváth L. 2018: A Szentai-erdő talajvízszint változásai a Kaszó-Life projekt hatására. Erdészettudományi Közlemények 8(2): 17-23. DOI: 10.17164/EK.2018.018

Führer E. 2018: A klímaértékelés erdészeti vonatkozásai. Erdészettudományi Közlemények 8(1): 27-42. DOI: 10.17164/ EK.2018.002

Garamszegi B., Nagy-Khell M., Farkas M. \& Nagy L. 2018: Az időjárási viszonyok hatása mézgás éger és kocsányos tölgy állományok növekedésére talajvízháztartás javítását célzó beavatkozások mellett. Erdészettudományi Közlemények 8(2): 9-16. DOI: 10.17164/EK.2018.017

Gálos B. \& Führer E. 2018: A klíma erdészeti célú előrevetítése. Erdészettudományi Közlemények 8(1): 43-55. DOI: 10.17164/EK.2018.003

Lakatos M. \& Bihari Z. 2011: A közelmúlt megfigyelt hőmérsékleti és csapadéktendenciái. In: Bartholy J., Bozó L. \& Haszpra L. (eds): Klímaváltozás - 2011, Klímaszcenáriók a Kárpát-medence térségére. MTA-ELTE, Meteorológia Tanszék, Budapest, 146-169.

Michel A., Prescher A-K. \& Schwärzel K. 2019: Forest Condition in Europe: 2019 Technical Report of ICP Forests. Report under the UNECE Convention on Long-range Transboundary Air Pollution (Air Convention). BFW-Dokumentation 27/2019. Vienna: BFW Austrian Research Centre for Forests. 104.

Majer J., Bordács M. \& Borhidi A. 2002: A Baláta-tó vízminőségének alapállapot felvételezése. Somogyi Múzeumok Közleményei 15: 97-106.

Nagy J. \& Nagy E. D. 2012: Kaszó 600 éve, tényekben, anekdotákban és képekben. Kaszó Zrt. Kaszó, ZPress Bt. - Berzence.

Paulin M., Hirka A., Mikó Á., Tenorio-B. I., Eötvös Cs., Gáspár Cs. \& Csóka Gy. 2020: A tölgy-csipkéspoloska Magyarországon - Helyzetkép 2019 öszén. Növényvédelem 81(6): 245-250.

Somogyi Z. 2018: A klímaváltozás miatti fapusztulás tovább gyorsíthatja a klímaváltozást. Erdészettudományi Közlemények 8(1): 213-228. DOI: 10.17164/EK.2018.013

Tóth J. 2003: Erdővédelmi mérőháló a HM Kaszó Erdőgazdaság területén. ERTI Jelentés, Erdővédelmi Osztály.

Érkezett: 2020. szeptember 17.

Közlésre elfogadva: 2020. október 15. 